\title{
Motivation Factors for Adopting Building Information Modeling (BIM) in Iraq
}

\author{
Wadhah Amer Hatem \\ Baquba Technical Institute \\ Middle Technical University \\ Baquba, Iraq \\ wadhah1970wadhah@gmail.com
}

\author{
Abbas Mahde Abd \\ Architecture Engineering Department \\ Diyala University of Engineering \\ Baquba, Iraq \\ abbas.mahd@gmail.com
}

\author{
Nagham Nawwar Abbas \\ Civil Engineering Department \\ Diyala University of Engineering \\ Baquba, Iraq \\ nagham.nawwar@gmail.com
}

\begin{abstract}
Building information modeling (BIM) is an integrated and comprehensive system including whatever is related to a construction project and its stages. It represents a unified database for all project data through which project documents are available to all stakeholders. This paper evaluates the factors driving the adoption of BIM in Iraqi construction projects in different ministries and adopts quantitative approach to collect data by using a questionnaire survey specially prepared for this purpose which was distributed to experts in the ministries of the Iraqi construction sector. Returned data were subjected to proper statistical analysis. Results showed that the highest motivation for BIM application is to include it in the educational curricula, raise awareness through courses and workshops and contracting with international experts with experience in BIM field.
\end{abstract}

Keywords-construction project; building information modelling; BIM; Iraq; motivation factor

\section{INTRODUCTION}

Construction industry is witnessing a paradigm shift that tends to achieve higher productivity, efficiency, quality, sustainability and infrastructure value while reduces the life cycle costs and time $[1,2]$. One of these techniques is building information modeling (BIM) which is a technological and procedural shift in the construction industry [3]. Actually, the evolution of computer science as well as information technology has caused a positive change in the processes of most industries [4]. BIM is an advanced process consisting of a combination of virtual aspects, systems and concepts facilitated within a unified environment [5]. It includes the application and keeping of integrated digital representation of different information across different project stages $[6,7]$. There are many BIM applications [8] which can be used to support constructability, scheduling, analysis, cost estimating and sequencing [9]. BIM as a new paradigm has a great potential for integration into the life cycle of construction projects [10, 11]. One of the main benefits of BIM is the accurate geometrical representation of building parts within an integrated information environment [12]. Furthermore, BIM reduces the duration and cost of the project, improves maintenance management and increases the building value [7]. BIM also improves communication between the different project parties [13]. On the other hand, BIM as a new phenomenon seeks to renew the practices of the construction industry, so it is subject to several challenges facing its application [14]. For the implementation of BIM, good planning and a coordinated approach with considerations for implementation and innovation management is required.

\section{FACTORS MOTIVATING THE APPLICATION OF BIM}

When authors in [15] investigated the factors that motivate the application of the BIM, he concluded that the two most important factors were leadership and a supportive environment. Author in [16] agreed on the importance of leadership as a key point in facilitating the application of BIM. The government should take the leadership role in the implementation of the BIM, but this is not enough. It should support and cooperate with other parties who have an impact on the development of Iraqi projects, such as specialists in the private sector, contractors or other specialists [16]. Making BIM mandatory was considered by specialists as an effective way to motivate institutions to move to BIM as this experience proved to be successful in the UK, USA, and Singapore [16]. In the context of mentioning cooperation, authors in [17] pointed out that one of the most important points to facilitate the task of implementing the BIM is the deployment of new cultures urging cooperation among stakeholders. Providing adequate training and upgrading knowledge of BIM will enhance its application $[18,19]$. In the other hand, contracting with experienced BIM and professional trainees for BIM software is a step in facilitating the application and use of BIM [20]. Table I provides a summary of top BIM motivation factors according to previous researchers' studies.

\section{RESEARCH METHODOLOGY}

This paper studies the factors motivating the application of BIM in Iraq. The data were collected using the field survey method through the design of a special questionnaire for this purpose and its distribution to the engineers working in the Iraqi construction sector in both Ministry of Higher Education and Scientific Research and Ministry of Construction, Housing, Municipalities and Public Works (in Diyala Governorate as a case study). 
TABLE I. SUMMARY OF BIM MOTIVATION FACTORS IN PREVIOUS STUDIES

\begin{tabular}{|c|c|c|c|}
\hline $\begin{array}{l}\text { Country and } \\
\text { reference }\end{array}$ & Motivation factors for BIM adoption & $\begin{array}{l}\text { Country and } \\
\text { reference }\end{array}$ & Motivation factors for BIM adoption \\
\hline $\begin{array}{l}\text { USA } \\
{[21]}\end{array}$ & $\begin{array}{l}\text { - Strategies to reduce strong resistance } \\
\text { - Improve cooperation skills } \\
\text { - Acceptance of stakeholders to BIM }\end{array}$ & $\begin{array}{c}\text { Australia } \\
\text { [22] }\end{array}$ & $\begin{array}{l}\text { - Improvements in information technology (IT) } \\
\text { infrastructure } \\
\text { - Improvements in computer hardware and software } \\
\text { - Government interest through the adoption of BIM } \\
\text { for many demonstrator projects }\end{array}$ \\
\hline $\begin{array}{l}\text { USA } \\
{[18]}\end{array}$ & $\begin{array}{l}\text { - Increase the level of knowledge of BIM } \\
\text { - Provide adequate training } \\
\text { - Coordination among stakeholders in the project } \\
\text { - Provide adequate support by senior management for } \\
\text { BIM application. }\end{array}$ & $\begin{array}{c}\text { Australia } \\
\text { [23] }\end{array}$ & $\begin{array}{l}\text { - Coordination among stakeholders in the project } \\
\text { - Provide adequate support by senior management for } \\
\text { BIM application } \\
\text { - Contribution of different parties (education } \\
\text { providers, specialists, supply chain Alliances) to } \\
\text { develop broad lines towards application of BIM }\end{array}$ \\
\hline $\begin{array}{l}\text { UK } \\
{[24]}\end{array}$ & $\begin{array}{l}\text { - Adopting collaborative methods and approaches within } \\
\text { the design team } \\
\text { - Provide staff with experience in the field of BIM } \\
\text { - Provide contract forms that are suitable for use of BIM } \\
\text { - Development of standards for use of BIM }\end{array}$ & $\begin{array}{c}\text { Korea } \\
{[25]}\end{array}$ & $\begin{array}{l}\text { - Organizational and individual confidence towards } \\
\text { the use of new technology } \\
\text { - Provide adequate training } \\
\text { - Develop commitments to use BIM within the } \\
\text { organizations and firms } \\
\text { - The government's obligation to use BIM in projects }\end{array}$ \\
\hline $\begin{array}{c}\text { China } \\
{[26]}\end{array}$ & $\begin{array}{l}\text { - Prepare validation for BIM tools } \\
\text { - Pressure by government } \\
\text { - Coordination among stakeholders in the project }\end{array}$ & $\begin{array}{c}\text { Malaysia } \\
{[27]}\end{array}$ & $\begin{array}{l}\text { - Compelling and supporting by the government } \\
\text { - Provide adequate training } \\
\text { - Provide adequate support by senior management for } \\
\text { BIM application }\end{array}$ \\
\hline $\begin{array}{c}\text { Australia } \\
\text { [28] }\end{array}$ & $\begin{array}{l}\text { - Provide adequate support by senior management for } \\
\text { BIM application. } \\
\text { - Develop higher strategies that encourage cooperative } \\
\text { work, conflict resolution and reduce the strong } \\
\text { resistance to change towards new technologies } \\
\text { - Develop a plan for BIM adoption by the government. } \\
\text { - Not only training to expand knowledge of BIM, but } \\
\text { dealing with external organizations of investors and } \\
\text { experts with expertise in the field of BIM }\end{array}$ & $\begin{array}{c}\text { Nigeria } \\
\text { [29] }\end{array}$ & $\begin{array}{l}\text { - Increase the level of knowledge of BIM } \\
\text { - Expanding the scope of research related to BIM } \\
\text { - Provide adequate support by senior management for } \\
\text { BIM application. } \\
\text { - Provide adequate training } \\
\text { - Facilitate educational facilities for the purpose of } \\
\text { - } \text { supporting their use }\end{array}$ \\
\hline
\end{tabular}

A total of 130 questionnaires were distributed, 65 in the Ministry of Higher Education and Scientific Research and 65 in the Ministry of Construction, Housing, Municipalities and Public Works. 114 were returned at a response rate of $87.7 \%$. The questionnaire included two main parts: the first part is the personal information regarding the respondent: gender, age, academic qualification, specialization, group and work experience. The second part included 13 items representing the importance of motivation factors for the application of BIM designed in the five- Likert scale [30] from 1 to 5,1 being not important and 5 being very important. After the collection of the questionnaires, they were arranged, unloaded and analyzed using the statistical packaging for social science (SPSS) software, Version 24. The statistical analysis represents the creation of some descriptive statistics such as frequency, percentage, mean and standard deviation and also calculated the value of the relative importance index (RII) in order to give ranks to the items.

\section{RESULTS AND DISCUSSION}

\section{A. General Information for Respondents}

The demographic characteristics of target respondents are shown in Table II.

\section{B. Statistical Validity and Reliability}

Access to acceptable results within any research requires the use of accurate measurement instrument as one of the basic requirements. Among the main objectives of the researcher is to design his research tool and make it characterized by three main qualities (be meaningful, be accurate, be efficient) [31]. Therefore, validity and reliability tests were conducted on the obtained data from the pilot survey which was conducted before the main study. Validity of instrument can be defined as the degree to which the instrument measures what it is supposed to measure $[32,33]$. For the purpose of the test statistical questionnaire validity internal consistency was performed. Through internal consistency correlation coefficients between each element in a particular part are measured with the part as a whole [34]. Table III shows the values of the Spearman rho correlation and p-values for all items. Results showed that correlation coefficients ranged from 0.496 to 0.755 and all p-values were less than 0.05 which indicates that the items are consistent and valid to measure what has been set to measure. Reliability indicates the stability of the results when these are redistributed again for the same sample. One of the most common methods of calculating reliability and the value of the Cronbach's alpha constant from 0 to 1 and the closer to 1 indicates the high degree of reliability [35]. Table IV represents a classification for the degree of reliability according to the value of the Cronbach's alpha coefficient. When the Cronbach's alpha method was conducted for the questionnaire, the results were shown within the good limits with 0.899 value. This result confirms the reliability of the questionnaire. 
TABLE II. RESPONDENTS PROFILE

\begin{tabular}{|c|c|c|}
\hline Information about & Categories & Percentage (\%) \\
\hline \multirow[t]{2}{*}{ Gender } & Male & 77.2 \\
\hline & Female & 22.8 \\
\hline \multirow{4}{*}{ Age (years) } & $20-30$ & 32.1 \\
\hline & $31-40$ & 24.7 \\
\hline & $41-50$ & 32.1 \\
\hline & More than 51 & 11.1 \\
\hline \multirow{5}{*}{$\begin{array}{l}\text { Academic } \\
\text { qualification }\end{array}$} & Diploma & 1.8 \\
\hline & Bachelor & 75 \\
\hline & Master & 11.6 \\
\hline & Ph.D. & 10.6 \\
\hline & Other & 1 \\
\hline \multirow{5}{*}{ Specialization } & Architect & 6.3 \\
\hline & Civil Engineer & 64 \\
\hline & Electrical Engineer & 9.9 \\
\hline & Mechanical Engineer & 14.4 \\
\hline & Other & 5.4 \\
\hline \multirow{5}{*}{ Group (Job) } & Designer & 14 \\
\hline & Consultant & 9 \\
\hline & Project manager & 10 \\
\hline & Site engineer & 56 \\
\hline & Other & 11 \\
\hline \multirow{5}{*}{$\begin{array}{l}\text { Practical experience } \\
\text { (years) }\end{array}$} & Less than 5 & 19.5 \\
\hline & $5-10$ & 24.8 \\
\hline & $11-15$ & 15 \\
\hline & $16-20$ & 24.8 \\
\hline & More than 20 & 15.9 \\
\hline
\end{tabular}

TABLE III. INTERNAL QUESTIONNAIRE CONSISTENCY

\begin{tabular}{|c|c|c|}
\hline Motivation Factors & $\begin{array}{c}\text { Correlation } \\
\text { Coefficient }\end{array}$ & Sig. (2-tailed) \\
\hline M1 & $0.644^{* *}$ & 0.00 \\
\hline M2 & $0.751^{* *}$ & 0.00 \\
\hline M3 & $0.691^{* *}$ & 0.00 \\
\hline M4 & $0.773^{* *}$ & 0.00 \\
\hline M5 & $0.662^{* *}$ & 0.00 \\
\hline M6 & $0.683^{* *}$ & 0.00 \\
\hline M7 & $0.670^{* *}$ & 0.00 \\
\hline M8 & $0.679^{* *}$ & 0.00 \\
\hline M9 & $0.702^{* *}$ & 0.00 \\
\hline M10 & $0.714^{* *}$ & 0.00 \\
\hline M11 & $0.679^{* *}$ & 0.00 \\
\hline M12 & $0.625^{* *}$ & 0.00 \\
\hline M13 & $0.500^{* *}$ & 0.00 \\
\hline \multicolumn{2}{|c|}{ "Correlation is significant at the 0.05 level (2-tailed) } \\
\hline & **Correlation is significant at the 0.01 level (2-tailed) \\
\hline
\end{tabular}

TABLE IV. RELIABILITY CLASSIFICATION [35]

\begin{tabular}{|c|c|}
\hline Cronbach's alpha & Degree of reliability \\
\hline$\alpha \geq 0.9$ & Excellent \\
\hline $0.9>\alpha \geq 0.8$ & Good \\
\hline $0.8>\alpha \geq 0.7$ & Acceptable \\
\hline $0.7>\alpha \geq 0.6$ & Questionable \\
\hline $0.6>\alpha \geq 0.5$ & Poor \\
\hline $0.5>\alpha$ & Unacceptable \\
\hline
\end{tabular}

\section{Motivation Factors of BIM Adoption}

This part consisted of 13 items that motivate the application of BIM. These items were taken from previous studies after their adaptation, modification and integration at certain points. These items were then subjected to the respondents' view and the results were then analyzed. One of the techniques used in the analysis of data is the relative importance index (RII). The purpose of its use is to give a rank for each item in a particular part in the questionnaire [36]:

$$
\begin{aligned}
R I I & =\frac{\Sigma W}{\left(A^{*} N\right)} \\
R I I & =\frac{5\left(n_{5}\right)+4\left(n_{4}\right)+3\left(n_{3}\right)+2\left(n_{2}\right)+n_{1}}{5\left(n_{5}+n_{4}+n_{3}+n_{2}+n_{1}\right)}
\end{aligned}
$$

where $W$ is the weight given by respondents for each component (ranging from 1 to 5), $A$ represents the highest weight (which equals to 5) and $N$ represents the total number of respondents.

Sign test is equivalent to "One sample t test" and it is execute based on dealing with the value of a medium for a single sample that is not complying with the parametric test conditions and its idea is based on the assumption of the medium value for the distribution of the sample and then give "sign" for all the values of sample depending on the value of whether it is greater or less than the hypothesis medium and thus gives a binomial probability for the observed pattern of sample values [37]. The sign test of BIM motivation factors was performed with a cut off value of 4 and $61 \%$ percentage. For the Likert five point scale the assumption is that $61 \%$ for answer is equal or more than 4 . Table $\mathrm{V}$ illustrates the values of the descriptive statistics sign test results, the value of the relative importance index RII and the rank of the items according to (RII, mean and standard deviation).

Figure 1 shows the values of the relative importance index of the thirteen items. Results showed that M7 (establish an educational base for BIM by making it part of the curriculum education in universities) represented the highest rank. This result may have taken the top rank because Iraqi universities lack a curriculum related to BIM, especially in the early stages of the study. M1 (promote local awareness of BIM benefits through workshops and courses as well as specialized conferences) took second rank, probably because the Iraqi construction sector suffers from poor knowledge regarding BIM. The third rank is for M13 (contracting with international specialists with experience in BIM filed), because many countries have previous experience in the application of BIM and the use of their experts has a positive impact on the application of BIM in Iraq. Since all p-values in sign test results are less than 0.05 , and by the ratios shown in the Table, it is found that more than $0.61 \%$ of the respondents evaluated the BIM motivation factors as "Important" and "Very important".

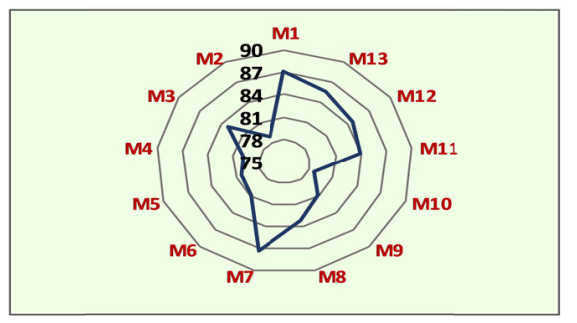

Fig. 1. Relative Importance Index (RII) for Motivations Factors 
TABLE V. RESULTS OF BIM MOTIVATION FACTORS STATISTICAL ANALYSIS

\begin{tabular}{|c|c|c|c|c|c|c|c|c|c|c|}
\hline \multirow{3}{*}{ NO } & \multirow{3}{*}{ Items } & \multicolumn{5}{|c|}{ Sign Test } & \multirow{3}{*}{ 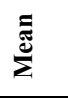 } & \multirow{3}{*}{ क) } & \multirow{3}{*}{$\stackrel{\partial}{a}$} & \multirow{3}{*}{ 茫 } \\
\hline & & \multicolumn{2}{|c|}{$\mathbf{N}$} & \multicolumn{2}{|c|}{ Observed Prop. } & \multirow{2}{*}{$\begin{array}{c}\text { Sig. 1- } \\
\text { tailed }\end{array}$} & & & & \\
\hline & & $\geq 4$ & $<4$ & $\geq 4$ & $<4$ & & & & & \\
\hline M1 & $\begin{array}{c}\text { Promote local awareness of BIM benefits } \\
\text { through workshops and courses as well as } \\
\text { specialized conferences }\end{array}$ & 100 & 14 & 0.88 & 0.12 & 0.000 & 4.36 & .82 & 87.19 & 2 \\
\hline M2 & $\begin{array}{l}\text { Government policy is to make use of BIM } \\
\text { mandatory through developing special laws }\end{array}$ & 83 & 31 & 0.73 & 0.27 & 0.006 & 3.93 & .97 & 78.77 & 12 \\
\hline M3 & $\begin{array}{l}\text { Provide government support for the } \\
\text { implementation of BIM in companies and firms }\end{array}$ & 93 & 21 & 0.82 & 0.18 & 0.000 & 4.15 & .86 & 83.16 & 7 \\
\hline M4 & $\begin{array}{c}\text { Detailed analysis of project life cycle costs to } \\
\text { convince the clients of financial returns from } \\
\text { using BIM }\end{array}$ & 91 & 23 & 0.80 & 0.20 & 0.000 & 3.99 & .92 & 79.82 & 11 \\
\hline M5 & $\begin{array}{l}\text { Disseminate positive views to reduce strong } \\
\text { resistance to change resulting from adhering to } \\
\text { traditional practices and programs }\end{array}$ & 92 & 22 & 0.81 & 0.19 & 0.000 & 4.01 & .89 & 80.35 & 10 \\
\hline M6 & Raise the level of public-private partnerships & 86 & 28 & 0.75 & 0.25 & 0.001 & 4.04 & .85 & 80.88 & 9 \\
\hline M7 & $\begin{array}{c}\text { Establish an educational base for BIM by } \\
\text { making it part of the curriculum education in } \\
\text { universities }\end{array}$ & 101 & 13 & 0.89 & 0.11 & 0.000 & 4.36 & .77 & 87.19 & 1 \\
\hline M8 & $\begin{array}{l}\text { Allocation of financial funding to support the } \\
\text { costs of BIM adoption }\end{array}$ & 93 & 21 & 0.82 & 0.18 & 0.000 & 4.16 & .83 & 83.16 & 6 \\
\hline M9 & $\begin{array}{l}\text { Raise awareness of cooperation culture } \\
\text { importance between different stockholders }\end{array}$ & 88 & 26 & 0.77 & 0.13 & 0.000 & 4.05 & .87 & 81.05 & 8 \\
\hline M10 & $\begin{array}{l}\text { Development of contracts and legal rules } \\
\text { governing the use of BIM }\end{array}$ & 83 & 31 & 0.73 & 0.27 & 0.005 & 3.93 & .84 & 78.60 & 13 \\
\hline M11 & $\begin{array}{l}\text { Raise the employment rate for fast-learning } \\
\text { ages of engineers }\end{array}$ & 95 & 19 & 0.83 & 0.17 & 0.000 & 4.20 & .89 & 83.86 & 5 \\
\hline M12 & $\begin{array}{l}\text { Develop skills of inexperienced engineers } \\
\text { through Specialized systematic programs }\end{array}$ & 99 & 15 & 0.87 & 0.13 & 0.000 & 4.22 & .94 & 84.56 & 4 \\
\hline M13 & $\begin{array}{l}\text { Contracting with international specialists with } \\
\text { experience in BIM filed }\end{array}$ & 94 & 20 & 0.82 & 0.18 & 0.000 & 4.28 & .93 & 85.61 & 3 \\
\hline
\end{tabular}

\section{CONCLUSION AND RECOMMENDATIONS}

This paper studied the factors that motivate the application of BIM in Iraq. This was discussed through a theoretical study that included a comprehensive survey of previous studies followed by analysis of the results of the survey that was prepared for this purpose and results showed that the highest three factors are "BIM is to include it in the educational curricula", "Raise awareness through courses and workshops", and "Contracting with international experts with experience in BIM". A set of recommendations are needed to be considered including the need to update the curricula of civil engineering and architecture and these curricula should be working on student development in both modelling skills using BIM tools as well as working skills within the BIM collaborative environment. Also, the need to raise the level of knowledge in BIM by providing courses, conferences and training workshops about it, provide material and moral support by various organizations and finally the importance of attracting internationally individuals competent with extensive experience in the field of BIM.

\section{REFERENCES}

[1] Y. Arayici, F. Khosrowshahi, A. M. Ponting, S. A. Mihindu, "Towards implementation of building information modelling in the construction industry", 5th International Conference on Construction in the 21st Century, "Collaboration and Integration in Engineering, Management and Technology", Istanbul, Turkey, pp. 1342-1351, May 20-22, 2009

[2] S. Azhar, A. Nadeem, J. Y. N. Mok, B. H. Y. Leung, "Building Information Modeling (BIM): A new paradigm for visual interactive modeling and simulation for construction projects", 1st International Conference on Construction in Developing Countries, Karachi, Pakistan, Vol. 1, pp. 435-446, August 4-5, 2008

[3] B. Succar, "Building information modelling framework: A research and delivery foundation for industry stakeholders", Automation in Construction, Vol. 18, No. 3, p. 357-375, 2009

[4] C. T. W. Chan, "Barriers of Implementing BIM in Construction Industry from the Designers' Perspective: A Hong Kong Experience", Journal of System and Management Sciences, Vol. 4, No. 2, pp. 24-40, 2014

[5] S. Azhar, M. Khalfan, T. Maqsood, "Building information modelling (BIM): now and beyond", Construction Economics and Building, Vol. 12 , No. 4, pp. 15-28, 2015

[6] K. Barlish, K. Sullivan, "How to measure the benefits of BIM-A case study approach", Automation in construction, Vol. 24, pp. 149-159, 2012

[7] C. M. Eastman, P. Teicholz, R. Sacks, K. Liston, BIM handbook: A guide to building information modeling for owners, managers, designers, engineers and contractors, John Wiley \& Sons, 2011

[8] Y. Arayici, C. Egbu, P. Coates, "Building information modelling (BIM) implementation and remote construction projects: issues, challenges, and critiques", Journal of Information Technology in Construction, Vol. 17, pp. 75-92, 2012

[9] A. H. Memon, I. A. Rahman, I. Memon, N. I. A. Azman, "BIM in Malaysian construction industry: status, advantages, barriers and strategies to enhance the implementation level", Research Journal of Applied Sciences, Engineering and Technology, Vol. 8, No. 5, pp. 606614,2014

[10] L. Chen, H. Qu, "Evaluation for "economics and legislative factors influence the design team and contractor throughout a building project from inception to completion", Journal of System and Management Sciences, Vol. 1, No. 6, pp. 94-108, 2011

[11] G. Nagalingam, H. S. Jayasena, K. A. T. O. Ranadewa, "Building information modelling and future quantity surveyor's practice in Sri 
Lankan construction industry", 2nd World Construction Symposium, Colombo, Sri Lanka, pp. 81-92, June 14-15, 2013

[12] CRC for Construction Innovation, Adopting BIM for facilities management: Solutions for managing the Sydney Opera House, Cooperative Research Center for Construction Innovation, 2007

[13] W. A. Hatem, A. Kwan, J. Miles, "Comparing the effectiveness of face to face and computer mediated collaboration", Advanced Engineering Informatics, Vol. 26, No. 2, pp. 383-395, 2012

[14] T. G. Kekana., C. O. Aigbavboa, W. D. Thwala, "Building Information Modelling (BIM): Barriers in Adoption and Implementation Strategies in the South Africa Construction Industry", Planetary Scientific Research Center Conference Proceedings, Vol. 76, pp. 109-111, 2014

[15] B. Ozorhon, C. Abbott, G. Aouad, "Innovation in construction: A project life cycle approach", Salford Centre for Research and Innovation in the Built Environment (SCRI) Research Report 4, pp. 903-1012, 2010

[16] P. Smith, "BIM implementation-global strategies", Procedia Engineering, Vol. 85, pp. 482-492, 2014

[17] A. Akintoye, J. Goulding, G. Zawdie, Construction innovation and process improvement, John Wiley \& Sons, 2012

[18] N. Zikic, Building Information Modeling Uses for Design in the Architecture, Engineering, and Construction (AEC) Industry, MSc Thesis, Pennsylvania State University, 2009

[19] A. A. Latiffi, S. Mohd, U. S. Rakiman, "Potential Improvement of Building Information Modeling (BIM) Implementation in Malaysian Construction Projects", in: Product Lifecycle Management in the Era of Internet of Things, pp. 149-158, 2015

[20] M. Abubakar, Y. M. Ibrahim, K. Bala, "Contractors' Perception of the Factors Affecting Building Information Modelling (BIM) Adoption in the Nigerian Construction Industry", International Conference on Computing in Civil and Building Engineering, pp. 167-178, June 2014

[21] W. Kymmell, Building Information Modeling: Planning and Managing Construction Projects with 4D CAD and Simulations (McGraw-Hill Construction Series): Planning and Managing Construction Projects with 4D CAD and Simulations, McGraw Hill Professional, 2007

[22] C. Furneaux, R. Kivvits, BIM-implications for government, CRC for Construction Innovation, 2008

[23] J. Mitchell, "BIM \& building simulation", Proceedings of Building Simulation Vol. 12, 12th Conference of International Building Performance Simulation Association, 2011

[24] D. Sinclair, BIM overlay to the RIBA outline plan of work, RIBA, 2012

[25] S. K. Lee, J.-H. Yu, "Effects of intrinsic and extrinsic motivation factors on BIM acceptance", Journal of the Korea Institute of Building Construction, Vol. 13, No. 3, pp. 242-252, 2013

[26] T. Kekana, C. Aigbavboa, W. Thwala, "Building Information Modelling (BIM): Barriers in Adoption and Implementation Strategies in the South Africa Construction Industry", International Conference on Emerging Trends in Computer and Image Processing, Pattaya, Thailand, December 14-15, 2014

[27] Z. Zahrizan, M. A. Nasli, T. H. Ahmad, A. Marshall-Pointing, A. H. Zuhairi, "Exploring the barriers and driving factors in implementing Building Information Modelling (BIM) in the malaysian construction industry-a preliminary study", Journal Institution of Engineers Malaysia, Vol. 75, No.1, pp. 1-10, 2014

[28] B. Abbasnejad, M. Nepal, R. Drogemuller, "Key enablers for effective management of BIM implementation in construction firms", CIB World Building Congress 2016: Volume I-Creating built environments of new opportunities, Tampere University of Technology, pp. 622-634, 2016

[29] A. O. Akerele, E. Moses, "Assessment of the Level of Awareness and Limitations on the Use of Building Information Modeling in Lagos State", International Journal of Scientific and Research Publications, Vol. 6, No. 2, pp. 229-233, 2016

[30] R. Likert, "The likert-type scale", Archives of Psychology, Vol. 140, pp. $1-55,1932$

[31] S. Behjati, Handbook of Research Instrument: basic review of the validity and reliability of measurement, CreateSpace Independent Publishing Platform, 2015
[32] J. Pallant, SPSS Survival Manual: A Step by Step Guide to Data Analysis Using IBM SPSS, Allen \& Unwin, 2016

[33] R. M. Furr, V. R. Bacharach, Psychometrics: An Introduction, SAGE Publications, 2013

[34] G. Garson, Validity and Reliability (Statistical Associates Blue Book Series 12), Kindle Edition, Statistical Associates Publishers, 2013

[35] R. D. Yockey, SPSS Demystified: A Simple Guide and Reference, Taylor \& Francis, 2016

[36] M. Rajgor, C. Paresh, P. Dhruv, P. Chirag, B. Dhrmesh, "Rii \& Impi: Effective Techniques For Finding Delay In Construction Project", International Research Journal of Engineering and Technology, Vol. 3, No. 1, pp. 1173-1177, 2016

[37] E. T. Berkman, S. P. Reise, A conceptual guide to statistics using SPSS, Sage, 2011 